\title{
Supplementation of maize silage or mixed forage (maize and grass silage) based rations with rumen protected methionine for dairy cows
}

\author{
P Brunschwig 1, P Augeard 2, B Sloan 3, K Tanan 4 \\ 1/nstitut de l'Elevage, 14 avenue Joxé, BP 646, 49006 Angers Cedex 01 ; 'Chambre d'Agriculture de Maine-et- \\ Loire, EDE, La Quantinière, 49800 Trélazé ; ${ }^{R}$ hhône Poulenc Nutrition Animale, 42 avenue A Briand, BP 100, \\ 92164 Antony Cedex; “Association Gala, 14 rue des Beaux-Soleils, BP 220, 95520 Osny, France
}

Methionine and lysine are the two amino acids most often implicated as being present in insufficient amounts to optimise milk protein output, and in particular milk protein content (Rulquin, 1992, INRA Prod Anim, 5(1), 29-36). Brunschwig et al (1994, Ann Zootech, 43, suppl 1,60 s) observed an increase in milk protein content of $+1.5 \mathrm{~g} / \mathrm{kg}$ in early lactation cows fed a maize silage based ration formulated to be optimal in digestible lysine (LysDI) content (\% PDIE) supplemented with $12 \mathrm{~g}$ of rumen protected methionine (Smartamine ${ }^{\mathrm{TM}} \mathrm{M}$ ). The aim of this study was to investigate if the energy value of the maize silage fed or the substitution of part of the total forage by grass silage influenced the response to $12 \mathrm{~g}$ of Smartamine ${ }^{\mathrm{TM}} \mathrm{M}$.

Three groups of fourteen dairy cows, post peak lactation, were fed one of three total mixed rations for a period of sixteen weeks. Rations M1 and M2 comprised $80 \%$ maize silage, $20 \%$ concentrate $(63 \%$ soyabean meal, and 33 and $4 \%$ of formaldehyde treated soyabean meal and rapeseed meal respectively). The two rations differed with respect to silage digestible organic matter content (655 vs $634 \mathrm{~g} / \mathrm{kg}$ DM). The third ration (MR) comprised $38 \%$ maize silage, $38 \%$ Italian ryegrass silage and $24 \%$ concentrate (24\% soyabean meal, $33 \%$ wheat, $39 \%$ and $4 \%$ formaldehyde treated soyabean and rapeseed meal respectively).
During the trial period the dairy cows in each group received 0 (C) or $12 \mathrm{~g}(\mathrm{AA})$ of Smartamine ${ }^{\mathrm{TM}} \mathrm{M}$, daily in one feed, according to a double switchback design, employing four periods of four weeks.

Ration concentrations were $0.90,0.86$ and 0.95 UFL $/ \mathrm{kg} \mathrm{DM}, 115,111$ and $114 \mathrm{~g} \mathrm{PDI} / \mathrm{kg}$ DM, 6.94, 6.94 and 6.94 LysDI (\% PDIE) for rations M1, M2 and MR respectively. The animal production responses are shown in table. Neither intakes, milk yiels nor milk fat content were significantly influenced by the supplementation with Smartamine ${ }^{\mathrm{TM}} \mathrm{M}$. Milk protein content was however improved significantly for cows on all rations. The increases to Smartamine ${ }^{\mathrm{TM}} \mathrm{M}$ supplementation were $+1.3,+1.4$ and $+1.0 \mathrm{~g} / \mathrm{kg}$ for rations $\mathrm{M} 1$, $\mathrm{M} 2$ and MR respectively.

These results indicate that energy concentration of the ration does not appear to influence the potential response to Smartamine supplementation. Although it could not be tested statistically, the milk protein responses on the uniquely maize silage based rations appeared greater compared to ration MR. This was probably related to the MetDI (\% PDIE) value of ration MR (1.76) being already higher before Smartamine ${ }^{\mathrm{TM}} \mathrm{M}$ supplementation compared to rations $\mathrm{M} 1$ (1.73) or $\mathrm{M} 2$ (1.74) and not a direct effect of including grass silage in the ration.

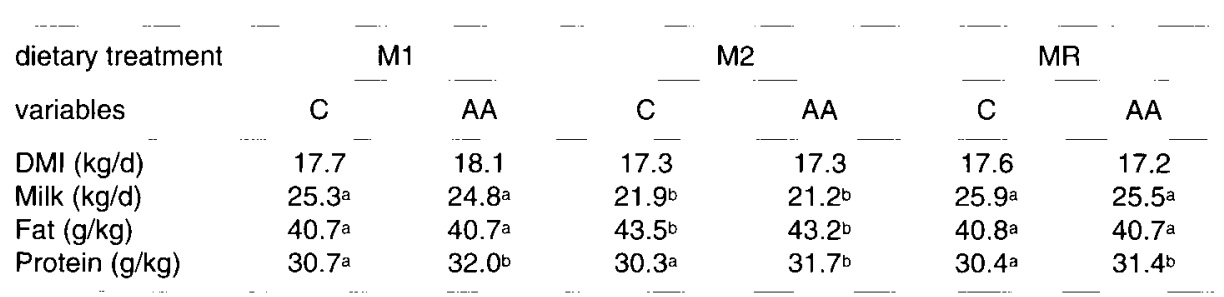

$a, b$ means within rows and treatment with different superscripts differ $\overline{(\mathrm{P}<0.05)}$ 